\title{
Common Bacterial Blight of Snap Bean in Florida1
}

\author{
Shouan Zhang, Aaron J. Palmateer, Ken Pernezny and Jeffrey B. Jones ${ }^{2}$
}

Common bacterial blight, caused by Xanthomonas campestris pv. phaseoli, is the most frequently encountered bacterial disease of snap bean in Florida. This disease is a major problem of both snap beans and dry beans worldwide where beans are grown. Common bacterial blight is particularly severe in warm, humid climates with significantly heavy rainfall.

Two other bacterial diseases of beans, halo blight and brown spot, caused by Pseudomonas syringae pv. phaseolicola and $P$. s. pv. syringae, respectively, are well known in many bean production areas. These two diseases tend to cause problems in cool weather. However, to our knowledge, outbreaks of these two diseases are unusual in Florida.

\section{Symptoms}

Leaf symptoms of common bacterial blight first appear as small, water-soaked spots (Fig. 1), usually more evident on the underside of the leaves. The lesions become larger and develop into dry, brown spots with distinct, rather narrow, yellow halos (Fig. 2). Spots may coalesce, and the yellowing of leaves becomes more general (Fig. 3).

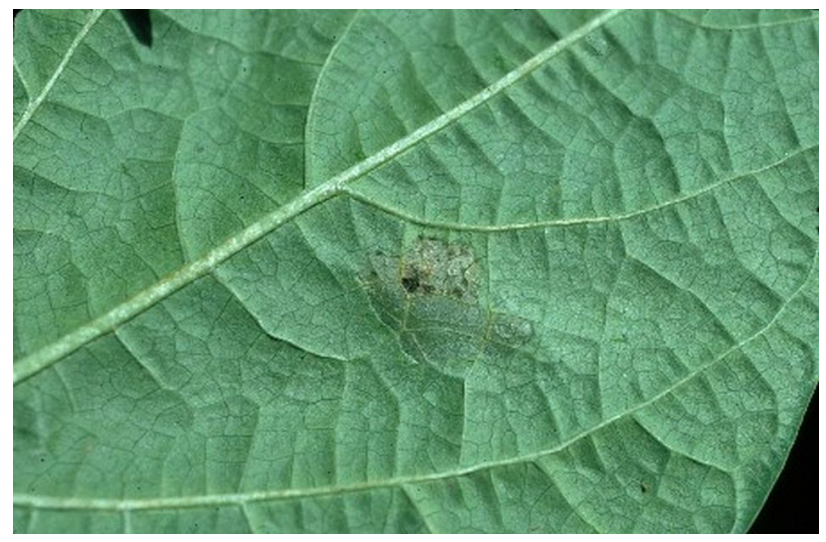

Figure 1. Initial symptoms associated with common bacterial blight on underside of bean leaves consist of water-soaked lesions. Credits: Courtesy Howard Schwartz

Symptoms on pods are quite striking with development of large, water-soaked areas (Fig. 4). These areas are more or less circular and slightly sunken. As symptoms process, pod lesions can become distinctly brick-red in color and more deeply pitted (Fig. 5). Under highly humid conditions, pod lesions become covered with a yellowish bacterial ooze that can dry to a yellowish, crusty mass. Interestingly, in South Florida, significant pod symptoms can appear with little foliar damage.

1. This document is PP-62, one of a series of the Plant Pathology Department, Florida Cooperative Extension Service, Institute of Food and Agricultural Sciences, University of Florida. Original publication date, June 2002. Revised February 2009. Visit the EDIS Web site at http:/edis.ifas.ufl.edu.

2. Shouan Zhang and Aaron J. Palmateer, assistant professors, Plant Pathology Department, Tropical Research and Education Center--Homestead, FL; Ken Pernezny, professor, Plant Pathology Department, Everglades Research and Education Center--Belle Glade, FL, and Jeffrey B. Jones, professor, Plant Pathology Department, Cooperative Extension Service, Institute of Food and Agricultural Sciences, University of Florida, Gainesville, FL. 


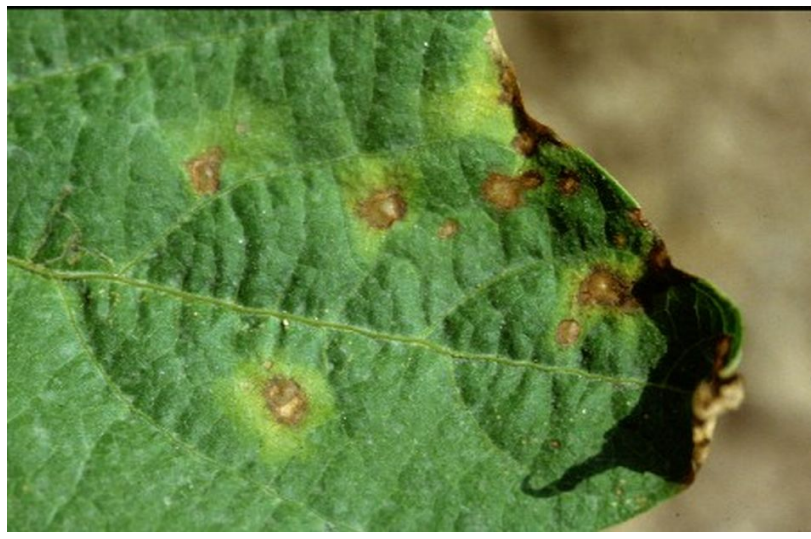

Figure 2. More advanced lesion of common bacterial blight on top surface of bean leaf showing beginning of chlorotic (yellow) halo around lesion.

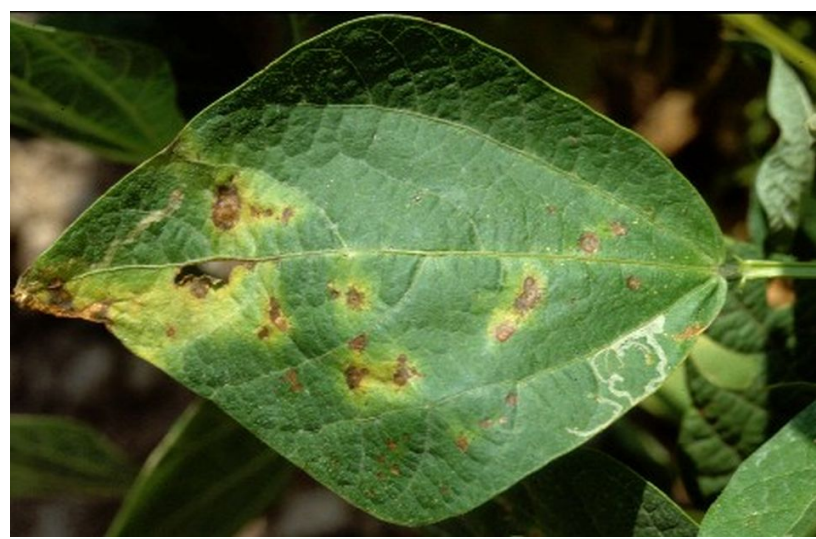

Figure 3. Numerous lesions of common bacterial blight on bean leaf.

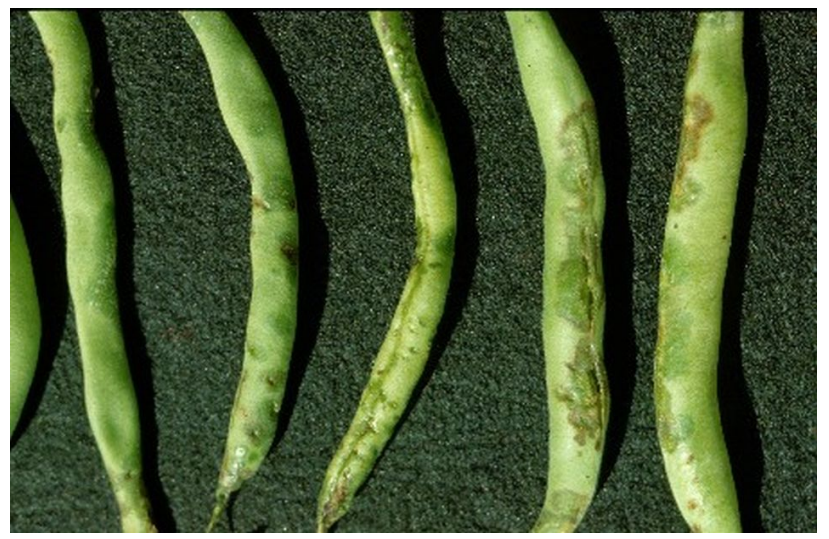

Figure 4. Striking water-soaking symptoms of common bacterial blight on bean pods.

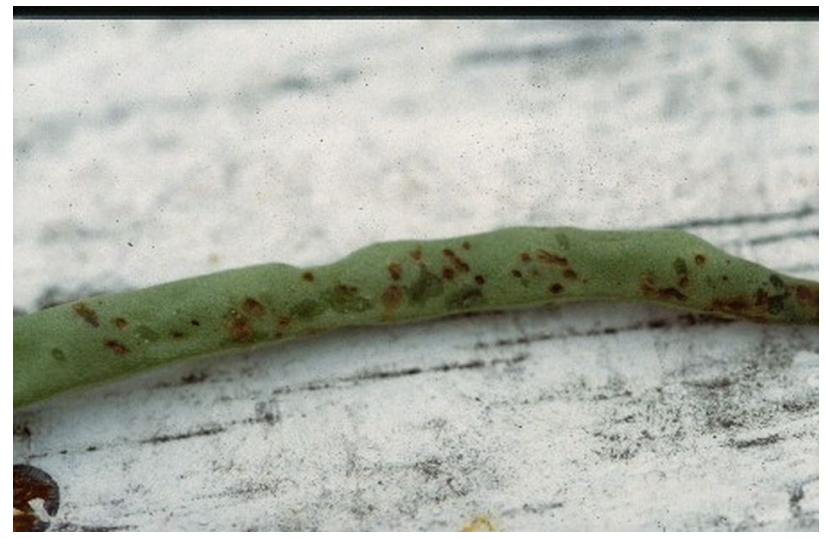

Figure 5. Advanced symptoms on bean pods, with appearance of characteristic brick-red areas in center of lesions.

\section{Cause and Disease Cycle}

The causal bacterium of common bacterial blight, Xanthomonas campestris pv. phaseoli, is related to bacteria that cause devastating bacterial diseases of tomato, pepper, citrus, lettuce, and many ornamental crops in Florida. X. c. pv. phaseoli has a limited host range, affecting snap bean, dry beans, scarlet runner bean, and a few other members of the legume family.

Contaminated seed is probably the major source of bacteria introduced into new fields of bean crops. Water-soaked lesions in young bean plants may be caused by cells of $X . c$. pv. phaseoli from seed as these cells invade emerging seedlings. The bacterial cells may colonize the surface of shoot tissues, inciting more disease later, when favorable conditions are present.

$X . c$. pv. phaseoli may survive in crop debris in the soil from season to season. However, such survival may not be realistic in South Florida -where the non-cropping period occurs in the hot, wet summer, and decomposition of crop debris is rapid and thorough. Significant populations of $X . c . p v$. phaseoli would hardly survive beyond six weeks under such conditions. However, X. c. pv. phaseoli can survive and multiply as an epiphyte or resident on the shoot surfaces of weed hosts, primarily members of the legume family. Alternative weed hosts, without showing symptoms, may also serve as sources of inoculum for this pathogen in Florida. 
Common bacterial blight causes significant damage at warm temperatures (82-90 degrees F for daytime highs). Rainfall or overhead irrigation (as from "rainbird" machinery in Homestead, Fla.) is usually favorable for disease development and progression in the field. Splashing water spreads the bacterial pathogen from diseased plants to healthy plants.

Cells of X. c. pv. phaseoli enter bean plants through openings, such as stomates (breathing pores) in leaves and other plant organs and through hydathodes (vein endings) at margins of leaves. Wounding of plants, such as that created by wind-blown soil particles, can create portals for ingress of blight bacteria. Bacteria are also readily transmitted mechanically, especially when field plants are wet. Particularly, insects -- such as whiteflies, leafminers, and beetles -- may transmit the bacterium from plant to plant. Cells of $X . c$. pv. phaseoli may invade and travel within the vascular (water-conducting) tissue of the bean plant.

\section{Control}

1. Plant pathogen-free seed, preferably from plants grown in dry environments, under furrow or similar irrigation.

\section{AVOID MOVEMENT THROUGH AND} WORK IN FIELDS WHEN PLANTS ARE WET. This simple cultural practice can greatly reduce blight disease development and spread.

3. Promptly destroy crops and disc in residues.

4. Control leguminous weeds that may serve as inoculum reservoirs. Insects should be properly controlled, particularly whiteflies.

5. Sprays of fixed copper bactericides (fungicides) may provide some control once disease appears. For more on specific, legal uses of pesticides for control of common bacterial blight, consult current labels and the University of Florida, IFAS, Plant Disease Management Guide -http://edis.ifas.ufl.edu/ topic_book_plant_disease_management_guide. 